\title{
Role of endothelin-1 in acute lung injury
}

\author{
ALEJANDRO P. COMELLAS ${ }^{*}$ and ARTURO BRIVA \\ Division of Pulmonary, Critical Care and Occupational Medicine. University of lowa, lowa City, \\ lowa; Departamento de Fisiopatologia, Facultad de Medicina, Universidad de la Republica, \\ Montevideo, Uruguay
}

\section{Abstract}

The alveolar-capillary membrane serves as a barrier that prevents the accumulation of fluid in the alveolar space and restricts the diffusion of large solutes while facilitating an efficient gas exchange. When this barrier becomes dysfunctional, patients develop acute lung injury (ALI), which is characterized by pulmonary edema and increased lung inflammation that leads to a lifethreatening impairment of gas exchange. In addition to the increase of inflammatory cytokines, plasma levels of endothelin-1 (ET-1), which is a primarily endothelium-derived vasoconstrictor, are increased in patients with ALI. As patients recover, ET-1 levels decrease, which suggests that ET-1 may not only be a marker of endothelial dysfunction but may have a role in the pathogenesis of ALI. While pulmonary edema accumulates, alveolar fluid clearance (AFC) is of critical importance, as failure to return to normal clearance is associated with poor prognosis in patients with pulmonary edema. AFC involves active transport mechanisms where sodium $\left(\mathrm{Na}^{+}\right)$is actively transported from the alveolar airspaces, across the alveolar epithelium, and into the pulmonary circulation, which creates an osmotic gradient that is responsible for the clearance of lung edema. In this article, we review the relevance of ET-1 in the development of ALI, not only as a vasoconstrictor molecule but also by inhibiting AFC via the activation of endothelial ET-B receptors and generation. Furthermore, this review highlights the therapeutic role of drugs such as beta-adrenergic agonists and, in particular, of endothelin receptor antagonists in patients with ALI.

The alveolar-capillary barrier facilitates efficient gas exchange and restricts the accumulation of fluid and large solutes in the alveolar space. When this barrier becomes dysfunctional, patients develop acute lung injury (ALI), which is clinically defined by a ratio of arterial partial pressure of oxygen to a fraction of inspired oxygen $\left(\mathrm{PaO}_{2} / \mathrm{FiO} 2\right)$ of up to 300 and bilateral infiltrates on chest radiographs in the absence of left atrial hypertension. The more severe form of ALI is known as acute respiratory distress syndrome (ARDS), which has a similar definition as ALI except for a $\mathrm{PaO}_{2} / \mathrm{FiO}_{2}$ ratio of up to $200 .^{1,2}$ This syndrome of acute respiratory failure affects $\sim 190,000$ patients per year in the United States with a mortality rate of $40 \%$ to $50 \% .{ }^{3}$ Moreover, the costs of care for ALI in the United States per patient was approximately $\$ 48,000$ in $2005 .^{4}$

It is now widely accepted that the pathophysiology of ALI is driven by an aggressive inflammatory reaction that increases the permeability of the alveolo-capillary unit after events such as sepsis, pneumonia, aspiration, and trauma. ${ }^{5-8}$ Several cytokines, such as tumor necrosis factor alpha, interleukin (IL)-1, IL-6, and IL-8, have been found to be increased in bronchoalveolar lavage (BAL) fluid and in the plasma of patients with ALI. ${ }^{9-11}$ The development of lung injury seems to include the activation of the coagulation and inflammatory cascades, increased leukocyte rolling, adhesion and transmigration, fibrin

Reprint requests: Alejandro P. Comellas, Department of Internal Medicine, Division of Pulmonary, Critical Care, and Occupational Medicine, University of Iowa, 200 Hawkins Dr. C331-GH, Iowa City, Iowa 52242; alejandro-comellas@uiowa.edu. 
deposition, as well as dysfunction of the epithelial and endothelial barrier. ${ }^{12}$ The precise sequence of events that lead to ALI remains elusive and are likely to vary between clinical syndromes and individual patients; however, the dysfunction of the epithelial and endothelial barrier is crucial for the development of ALI. ${ }^{13-16}$

Patients with ALI have increased alveolar epithelial dysfunction markers such as KL-6 ${ }^{17}$ and receptor for advanced glycation end-products, ${ }^{18}$ as well as endothelial dysfunction markers such as endothelin-1 (ET-1). Interestingly, as these patients recover, ET-1 levels decrease, which suggests that ET-1 may not only be a marker of endothelial dysfunction, but also may have a role in the pathogenesis of ALI. ${ }^{19,20}$ Furthermore, Sartori et al ${ }^{21}$ reported that in another form of ALI known as high-altitude pulmonary edema (HAPE), susceptible mountaineers have augmented release concentrations of ET-1, potentially representing one of the mechanisms contributing to HAPE.

\section{ENDOTHELIN SYSTEM}

The endothelins are a family of 21 amino acid peptides, of which 3 distinct isoforms exist (ET-1, ET-2, and ET-3). These potent vasoactive peptides are released from biologic inactive precursors (big endothelin) by the endothelin-converting enzymes, which are a subgroup of membrane-bound zinc metalloproteases. ${ }^{22}$ ET-1 is the most abundant isoform and the best characterized, ${ }^{23}$ and it is the only one released constitutively by the vascular endothelium. Its activity contributes to the maintenance of endogenous vasomotor tone by producing a long-lasting vasoconstriction of the underlying smooth muscle cells. ${ }^{24} \mathrm{In}$ addition, ET-1 is also produced by smooth muscle cells, ${ }^{25}$ cardiomyocites, ${ }^{26}$ leukocytes, ${ }^{26}$ macrophages, ${ }^{27}$ mesangial cells, ${ }^{28,29}$ airway epithelium, ${ }^{30-32}$ and alveolar epithelial cells (AECs). ${ }^{33,34}$ ET-1 is released during various injurious stimuli, including shear stress, thrombin, angiotensin II, cytokines, and free radicals, whereas atrial natriuretic peptide, prostacyclin, and NO inhibit its synthesis and release. ${ }^{35,36}$

ET-1 mediates all its different effects via activation of the ET-A and ET-B G-protein coupled receptors. ${ }^{23,36,37}$ When ET-1 binds to ET-A receptors, it activates phospholipase C (PLC), leading to the generation of the second messenger inositol triphosphate and diacylglycerol (DAG), which in turn stimulates calcium release and protein kinase $\mathrm{C}$ activation. ${ }^{38}$ Other signaling pathways described for ET-A receptors include phospholipase D (PLD)-mediated DAG generation, phospholipase A2 (PLA2)-induced arachidonic acid release, and activation of the mitogen-activated protein kinase cascade. These signaling pathways are involved in the short-term regulation of vascular smooth muscle tone as well as in the long-term control of cell growth in the vasculature and the heart. ${ }^{39}$ However, the ET-B receptor is expressed characteristically in cells that participate in several physiologic processes besides the modulation of vascular resistance, such as natriuresis, hepatic function, and neuronal activities. ${ }^{40-44}$ Moreover, the physiologic role of ET-1 is modulated by the location of the ET-B receptor. For example, its activation on smooth muscle cells mediates the vasoconstrictor responses of ET-1, whereas ET-B receptors located on endothelial cells stimulate the release of $\mathrm{NO}$ and prostacyclin, which causes a vasodilatory response. ${ }^{24,45,46}$ ET-B receptors are coupled to Gq/G11 proteins, and their activation recruits pathways dependent on PLC, PLA2, PLD, $\mathrm{Na}^{+} / \mathrm{H}^{+}$exchanger, adenylate and guanylate cyclases, intracellular $\mathrm{Ca}^{2+}$ mobilization, phosphatidylinositol 3-kinase, and Gprotein $\beta \gamma$ subunits. ${ }^{47-49}$ In addition, ET-1 is cleared from the circulation via ET-B receptors, primarily in the lung and secondarily in the kidney and liver. ${ }^{50}$

\section{ET-1 IN ACUTE LUNG INJURY}

As mentioned, 1 marker of endothelial dysfunction in patients with ALI is the presence of high ET-1 concentrations. ${ }^{19,23,51}$ However, it is uncertain whether ET-1 by itself increases 
protein or fluid transport into the lung. ${ }^{52-54}$ In a prospective observational study, Kuzkov et $\mathrm{al}^{55}$ demonstrated that extravascular lung water index (EVLWI) correlated directly with markers of ALI. The authors also showed that patients with increased EVLWI had significantly higher ET-1 concentrations, which suggests that ET-1 is involved in the evolution of pulmonary edema. The mechanisms involved in endothelin-induced pulmonary edema formation remain uncertain but may include alterations in vascular reactivity with an increase in capillary hydrostatic pressure; recruitment of inflammatory cells, which disrupts the endothelial/epithelial barrier; and upregulation of mediators that increase vascular permeability, such as vascular endothelial growth factor (VEGF), which is part of a family of angiogenic peptides that increase permeability of the endothelial barrier. ${ }^{56}$ ET-1 increases capillary hydrostatic pressure via a direct effect on the vascular bed by inducing systemic and pulmonary hypertension, ${ }^{57,58}$ while indirectly causing cardiac failure secondary to the development of bradycardia and depression of the myocardial function through a combination of systemic and coronary vasoconstriction. ${ }^{58}$ In addition, ET-1 increases capillary permeability via postcapillary vasoconstriction, which is dependent on the presence of inflammatory cells. ${ }^{52}$ Interestingly, several in vitro studies suggest that ET-1 promotes VEGF expression in different cell types, including alveolar epithelial and lung endothelial cells. ${ }^{59-61}$ The role of VEGF in the development of pulmonary edema was first established by Kaner et al, ${ }^{62}$ who demonstrated that overexpression of VEGF via an adenovirus gene transfer vector mediated high permeability pulmonary edema in C57B1/6 mice.

Subsequently, Carpenter et $\mathrm{al}^{60}$ showed that endothelin increases VEGF in the lung, which contributes to the formation of pulmonary edema.

Another piece of evidence that points toward the role of the endothelin system in the development of ALI is the fact that several endothelin receptor antagonists have been reported to exert protective effects in different models of ALI. ${ }^{63,64}$ As reported by Wang et $\mathrm{al},{ }^{65}$ the endothelin system is involved in chlorine-gas-induced lung injury as circulating ET-1 increased with chlorine gas exposure, which shows a significant relationship between circulating ET-1 and lung function variables. In this study, a blockade of endothelin receptors A \& B with a nonselective inhibitor, Tezosentan, ameliorated chlorine-gasinduced lung injury. Also, Kuklin et a ${ }^{58}$ designed a series of experiments to evaluate the role of Tezosentan in treated sheep with endotoxin-induced lung injury. Results showed that treated animals had decreased pulmonary hypertension, cardiac dysfunction, pulmonary edema, and hypoxemia. Furthermore, Carpenter et $\mathrm{al}^{66}$ reported that rats pre-treated with another nonselective endothelin receptor antagonist, Bosentan, and infected with Sendai virus followed by exposure to hypoxia $\left(\mathrm{FiO}_{2}=0.1\right)$ for $24 \mathrm{~h}$, developed less lung water accumulation, less lung lavage fluid protein, and less perivascular fluid cuffing than untreated animals.

Although most nonselective endothelin receptor antagonists prevent the development of ALI, studies that examined the effects of blocking specific endothelin receptors A or B have revealed contradictory results. Ishizaki et $\mathrm{al}^{67}$ reported that pretreatment of isolated rat lungs with the ET-A receptor antagonist, BQ-123, significantly attenuated the ET-1-induced increase in pulmonary arterial pressure and pulmonary capillary pressure. It also prevented the ET-1-induced and leukotoxin-induced lung edema. Conversely, Albertini et al ${ }^{68}$ reported that pretreatment of rats with another selective ET-A receptor antagonist, ABT-627, prevented endotoxin-induced mortality and significantly attenuated an increase of wet/dry ratios of the heart, liver, kidney, but not the lungs. In regard to the role of ET-B receptor, Guimaraes et al ${ }^{69}$ reported that pretreatment of mice with the ET-B receptor antagonist, Ro 46-8443, reduced oleic acid-induced increase permeability to Evans blue in mouse lungs and decreased the total number of neutrophils in the BAL. However, Carpenter et $\mathrm{al}^{70}$ reported that ET-B transgenic rats, which do not express ET-B receptors except in adrenergic tissues, 71,72 were predisposed to develop pulmonary edema under hypoxic conditions via an 
increase in lung expression of VEGF. These discrepancies can be potentially explained by several factors, which include the type of injury, whether the experiments were done in vivo or in isolated lungs, the animal species used, and the type and class of pharmacologic antagonists. It is also conceivable that the ET-A and ET-B play different roles in the development of ALI. These roles include (1) direct effects that increase endothelial and/or epithelial permeability, (2) indirect effects that increase migration of inflammatory cells into the lung parenchyma, and (3) impairment of the mechanisms that are involved in alveolar fluid clearance (AFC), such as active sodium transport and lymphatic drainage.

These results suggest that both ET-A and ET-B are involved in the development of ALI, and therefore, blocking both is required as a strategy to prevent the development of ET-1induced lung injury.

\section{AFC}

In ALI, an increase occurs in the permeability of the alveolar-capillary barrier, which in combination with changes in hydrostatic and oncotic pressures leads to the formation of pulmonary edema. ${ }^{73}$ However, once alveolar edema is fully formed, decreasing the preload does not affect the overall amount of edema. ${ }^{74}$

Approximately 3 decades ago, it was revealed that fluid balance in the lung was regulated by active ion transport mechanisms, ${ }^{75,76}$ whereas sodium $\left(\mathrm{Na}^{+}\right)$is actively transported from the alveolar airspaces, across the alveolar epithelium, and into the pulmonary circulation creating an osmotic gradient that is responsible for the clearance of lung edema. ${ }^{77-79}$ The clinical relevance of this mechanism is illustrated by the fact that failure to return to normal clearance is associated with poor prognosis in patients with pulmonary edema. ${ }^{80,81}$

As shown in Fig 1, the alveolar space consists of a monolayer of squamous type I cells [alveolar type 1 cell (ATI)] and cuboidal type II cells (ATII). The ATI cells cover 95\% of the alveolar surface, whereas the ATII cells are responsible for the secretion of surfactant. Both cell types are involved in vectorial transport of $\mathrm{Na}^{+}$from the apical to the basolateral surface. Although $\mathrm{Na}^{+}$uptake is driven by several $\mathrm{Na}^{+}$transport mechanisms, which include amiloride-sensitive (ENaC), amiloride-insensitive $\mathrm{Na}^{+}$channels and co-transporters of $\mathrm{Na}^{+}$, the only transporter by which AEC actively extrude $\mathrm{Na}^{+}$out of the cell is the sodiumpotassium-adenosine triphosphatase (Na, K-ATPase). ${ }^{16,82}$

The Na, K-ATPase is a transmembrane protein expressed on the basolateral surface of most mammalian epithelial cells that maintains an electrochemical gradient across the plasma membrane by pumping $\mathrm{Na}^{+}$out of the cell and $\mathrm{K}^{+}$into the cell against their respective concentration gradients in an ATP-dependent process. It is composed of a catalytic $\alpha$ subunit that comprises approximately 1000 amino acid residues, which spans the plasma membrane 10 times, and of the $\beta$ subunit, which seems to contribute to the stability of the $\alpha \beta$ complex and its insertion into the baso-lateral membrane. In addition, the $\alpha$-subunit contains sites for cleavage of high-energy phosphate bonds and binding of the classic Na, K-ATPase inhibitor, ouabain. ${ }^{83,84}$

A decrease in the number of Na, K-ATPase molecules at the plasma membrane, via endocytosis and subsequent protein degradation, results in inhibition of $\mathrm{Na}^{+}$transport and, thus, decreased AFC. ${ }^{85-88}$ Multiple pathophysiologic stimulus alter the Na, K-ATPase function in ALI, and these include, although are not limited to, hyperoxia, ${ }^{89,90}$ hypocapnic alkalosis, ${ }^{91}$ hypercapnia, ${ }^{85}$ ischemia/reperfusion injury, ${ }^{92}$ inflammatory events,,${ }^{93}$ and hypoxia. ${ }^{86,87,94}$ Therefore, regulation of the Na, K-ATPase represents an important and fundamental mechanism to modulate alveolar epithelial function. ${ }^{74,86}$ 


\section{ROLE OF ET-1 IN AFC}

The endothelium provides the interface between the blood and the extravascular tissue of the lungs, and normally, it restricts movement of water and protein. ${ }^{95}$ Sources of ET-1 include the endothelium and epithelium, and as mentioned, ET-1 is increased in serum and BAL of patients with ALI, which suggests the presence of a lung endothelial-epithelial dysfunction. 23,51,96,97 Also, an important stimulus for ET-1 release is hypoxia, ${ }^{98}$ and recent evidence, both in vivo and in vitro, suggests that hypoxia significantly reduces the capacity for active $\mathrm{Na}^{+}$transport across the alveolar epithelium. ${ }^{99-101}$ Because the alveolar epithelium is not accessible in humans, the nasal epithelium, which has $\mathrm{Na}^{+}$transporters that are similar to those of the alveolar epithelium, has been used to estimate alveolar epithelium $\mathrm{Na}^{+}$transport activity. ${ }^{102}$ Accordingly, hypoxia was found to inhibit nasal epithelial $\mathrm{Na}^{+}$transport in HAPE-susceptible but not in HAPE-resistant mountaineers. ${ }^{103,104}$ In addition, endothelin receptor antagonists have been studied in patients with HAPE. Modesti et $\mathrm{al}^{97}$ in a randomized double-blind placebo clinical trial determined the role of the nonselective ET-A and ET-B receptor antagonist bosentan in mountaineers with HAPE. The authors found that compared with placebo, bosentan induced a significant reduction of systolic pulmonary artery pressure and improved arterial oxygen saturation. In contrast, reports using other vasodilators, such as $\mathrm{NO}^{105}$ and Sildenafil, ${ }^{106}$ did not show beneficial effects. These differences may be explained by our recent report, where we describe that ET-1 activates endothelial ET-B receptors and increases NO concentrations, which in turn decreases $\mathrm{Na}, \mathrm{K}-$ ATPase activity in AEC, reducing AFC. ${ }^{34}$ Moreover, Berger et al ${ }^{107}$ recently reported similar results, showing that ET-B receptors are involved in the ET-1 induced AFC reduction in anesthetized rats.

It is well known that $\mathrm{NO}$ downregulates $\mathrm{ENaC}$ and $\mathrm{Na}$, K-ATPase activity in AEC, which impairs AFC. ${ }^{108-113}$ For instance, Guo et al ${ }^{108}$ showed inhibition of the Na, K-ATPase in ATII cells after exposure to a NO donor PAPA NONOate, and Kaestle et al ${ }^{112}$ reported that acute elevation of hydrostatic pressures in isolated perfused rat lungs caused an increase in endothelial NO levels, which lead to a decrease in AFC. However, researchers have debated whether the mechanisms involved in the NO induced AFC reduction, as several reports have described that NO downregulates active sodium transport in AEC via a cGMP-mediated inhibition of epithelial cation channels. ${ }^{109,111,112}$ Conversely, other authors have reported that $\mathrm{NO}$ decreases sodium absorption across AEC monolayers by inhibiting both $\mathrm{ENaC}$ and the Na, K-ATPase through a cGMP independent mechanism. ${ }^{34,76,108}$ Based on these studies, the data suggest that ET-1 is involved in the development of pulmonary edema, in part by activating endothelial ET- B receptors and NO generation, which in turn downregulates the different $\mathrm{Na}^{+}$transport mechanisms that are responsible for AFC in AEC (Fig 1).

\section{BETA-ADRENERGIC AGONIST ROLE IN PREVENTING ET-1-INDUCED AFC REDUCTION}

Beta-adrenergic agonists have been proposed as a potential therapy for ALI and were among the 1st agents shown to accelerate $\mathrm{Na}^{+}$transport by increasing the activity of $\mathrm{Na}^{+}$and Chloride $\left(\mathrm{Cl}^{-}\right)$channels and the Na, K-ATPase in the alveolar epithelium. ${ }^{82,114-118}$ Shortterm stimulation of $\beta 2$-adrenergic receptors by Isoproterenol (Iso) have been found to result in receptor-dependent activation of $\mathrm{G}$ proteins, which successively stimulates adenylyl cyclase, resulting in enhanced cyclic adenosine monophosphate (cAMP) generation and consequent activation of protein kinase A. ${ }^{119-122}$ In addition, $\beta 2$-receptor agonists have been shown to stimulate alveolar epithelial $\mathrm{Na}^{+}$and fluid transport in animal models, ${ }^{94,101}$ and to promote pulmonary edema reabsorption in patients with ALI. ${ }^{123}$ In a double-blind, randomized, placebo-controlled study, the prophylactic inhalation of salmeterol, which is a 
$\beta 2$ adrenergic receptor agonist, decreased the incidence of HAPE in susceptible subjects from $74 \%$ to $33 \% .{ }^{124}$ The authors of this study suggested that AFC may have played a part in this beneficial effect, because beta-adrenergic agonists upregulate the clearance of alveolar fluid by stimulating transepithelial $\mathrm{Na}^{+}$transport. Based on the above studies, we tested in a previously described model of isolated and perfused rat lung ${ }^{34}$ to determine whether Iso instillation in the airspace prevents the ET-1 induced AFC reduction. These experiments were conducted in accordance with both local institutional guidelines and the Guide for the Care and Use of Laboratory Animals (National Institutes of Health). As shown in Fig 2, instillation of ET-1 decreased AFC by $~ 50 \%$, whereas Iso increased AFC by $\sim 120 \%$. When Iso was instilled in the airspace, followed then by perfusion with ET-1, it prevented the ET-1 induced AFC reduction and increased AFC to similar levels of the Iso alone treated group. Interestingly, when isolated and perfused rat lungs were pretreated with ET-1, perfused for 30 minutes in the vascular circulation, and then followed by Iso instillation in the airspace, the AFC was similar to the control conditions, and it did not achieve the same level as in the Iso-treated group. This finding suggests that pretreatment of ET-1 partially impairs the mechanisms involved in the $\beta$-adrenergic-induced increase in AFC.

Although the results of clinical trials for pharmacologic treatment of ARDS have been disappointing, several promising treatment strategies are still evolving, which include agents that enhance edema clearance. It is conceivable that in some patients, the extent of alveolar epithelial injury and the severity of endothelial lung injury may preclude a therapeutic benefit of $\beta$-adrenergic agonists, at least in the early stages of the lung injury. However, as repair of the alveolar epithelium occurs, it is possible that the epithelial barrier may become responsive to cAMP stimulation, which hastens the resolution of alveolar edema. Currently, well-designed clinical studies are under way to test the potential therapeutic value of $\beta 2$ agonist therapy in patients with ARDS. ${ }^{125}$

\section{CONCLUSION}

In summary, clinical data suggest that ET-1 plays a role in the development of ALI, and experimental data, both in vivo and in vitro, demonstrates that ET-1 induces the formation of pulmonary edema via both ET-A and ET-B receptors. Also, endothelin receptor antagonists prevent the development of ALI, either via decreasing the permeability of the endothelial and epithelial barrier, or via reconstituting the ability of the alveolar epithelium to clear edema. Finally, based on all these findings, we propose that additional clinical trials will consider the use of endothelin receptor antagonists as a therapeutic tool in the treatment of patients with ALI.

\section{Acknowledgments}

Supported by Grant K01HL080966-01 from the NIH/National Heart, Lung, and Blood Institute.

\section{Abbreviations}

$\begin{array}{ll}\text { AEC } & \text { alveolar epithelial cells } \\ \text { AFC } & \text { alveolar fluid clearance } \\ \text { ALI } & \text { acute lung injury } \\ \text { ARDS } & \text { acute respiratory distress syndrome } \\ \text { BAL } & \text { bronchoalveolar lavage }\end{array}$




$\begin{array}{ll}\text { CAMP } & \text { cyclic adenosine monophosphate } \\ \text { DAG } & \text { diacylglicerol } \\ \text { EVLWI } & \text { extravascular lung water index } \\ \text { ENaC } & \text { amiloride sensitive sodium channel } \\ \text { ET-1 } & \text { endothelin-1 } \\ \text { FiO2 } & \text { fraction of inspired oxygen } \\ \text { HAPE } & \text { high-altitude pulmonary edema } \\ \text { Iso } & \text { isoproterenol } \\ \text { Na,K-ATPase } & \text { sodium, potassium-adenosine triphosphatase } \\ \text { PaO2 } & \text { arterial partial pressure of oxygen } \\ \text { PLA2 } & \text { phospholipase A2 } \\ \text { PLC } & \text { phospholipase C } \\ \text { PLD } & \text { phospholipase D } \\ \text { VEGF } & \text { vascular endothelial growth factor }\end{array}$

\section{References}

1. Bernard GR, Artigas A, Brigham KL, et al. The American-European Consensus Conference on ARDS. Definitions, mechanisms, relevant outcomes, and clinical trial coordination. Am J Respir Crit Care Med 1994;149:818-24. [PubMed: 7509706]

2. Phua J, Stewart TE, Ferguson ND. Acute respiratory distress syndrome 40 years later: time to revisit its definition. Crit Care Med 2008;36:2912-21. [PubMed: 18766113]

3. Rubenfeld GD, Caldwell E, Peabody E, et al. Incidence and outcomes of acute lung injury. N Engl J Med 2005;353:1685-93. [PubMed: 16236739]

4. Angus DC, Clermont G, Linde-Zwirble WT, et al. Healthcare costs and long-term outcomes after acute respiratory distress syndrome: a phase III trial of inhaled nitric oxide. Crit Care Med 2006;34:2883-90. [PubMed: 17075373]

5. Bellingan GJ. The pulmonary physician in critical care * 6: the pathogenesis of ALI/ARDS. Thorax 2002;57:540-6. [PubMed: 12037231]

6. Matthay MA, Zimmerman GA, Esmon C, et al. Future research directions in acute lung injury: summary of a National Heart, Lung, and Blood Institute working group. Am J Respir Crit Care Med 2003;167:1027-35. [PubMed: 12663342]

7. Piantadosi CA, Schwartz DA. The acute respiratory distress syndrome. Ann Intern Med 2004;141:460-70. [PubMed: 15381520]

8. Puneet P, Moochhala S, Bhatia M. Chemokines in acute respiratory distress syndrome. Am J Physiol Lung Cell Mol Physiol 2005;288:L3-15. [PubMed: 15591040]

9. Jacobs RF, Tabor DR, Burks AW, Campbell GD. Elevated inter-leukin-1 release by human alveolar macrophages during the adult respiratory distress syndrome. Am Rev Respir Dis 1989;140:S168692.

10. Miller EJ, Cohen AB, Nagao S, et al. Elevated levels of NAP-1/interleukin-8 are present in the airspaces of patients with the adult respiratory distress syndrome and are associated with increased mortality. Am Rev Respir Dis 1992;146:427-32. [PubMed: 1489135]

11. Suter PM, Suter S, Girardin E, et al. High bronchoalveolar levels of tumor necrosis factor and its inhibitors, interleukin-1, interferon, and elastase, in patients with adult respiratory distress syndrome after trauma, shock, or sepsis. Am Rev Respir Dis 1992;145:1016-22. [PubMed: 1586041]

12. Aird WC. Endothelial cell heterogeneity. Crit Care Med 2003;31:S221-30. [PubMed: 12682444] 
13. Berthiaume Y, Matthay MA. Alveolar edema fluid clearance and acute lung injury. Respir Physiol Neurobiol 2007;159:350-9. [PubMed: 17604701]

14. Komarova YA, Mehta D, Malik AB. Dual regulation of endothelial junctional permeability. Sci STKE 2007;2007:re8. [PubMed: 18000237]

15. Jacobson JR, Garcia JG. Novel therapies for microvascular permeability in sepsis. Curr Drug Targets 2007;8:509-14. [PubMed: 17430121]

16. Vadasz I, Raviv S, Sznajder JI. Alveolar epithelium and Na, K-ATPase in acute lung injury. Intensive Care Med 2007;33:1243-51. [PubMed: 17530222]

17. Ishizaka A, Matsuda T, Albertine KH, et al. Elevation of KL-6, a lung epithelial cell marker, in plasma and epithelial lining fluid in acute respiratory distress syndrome. Am J Physiol Lung Cell Mol Physiol 2004;286:L1088-94. [PubMed: 12959931]

18. Uchida T, Shirasawa M, Ware LB, et al. Receptor for advanced glycation end-products is a marker of type I cell injury in acute lung injury. Am J Respir Crit Care Med 2006;173:1008-15. [PubMed: 16456142]

19. Langleben D, DeMarchie M, Laporta D, et al. Endothelin-1 in acute lung injury and the adult respiratory distress syndrome. Am Rev Respir Dis 1993;148:1646-50. [PubMed: 8256914]

20. Mitaka C, Hirata Y, Nagura T, Tsunoda Y, Amaha K. Circulating endothelin-1 concentrations in acute respiratory failure. Chest 1993;104:476-80. [PubMed: 8339637]

21. Sartori C, Vollenweider L, Loffler BM, et al. Exaggerated endothelin release in high-altitude pulmonary edema. Circulation 1999;99:2665-8. [PubMed: 10338460]

22. Yanagisawa M, Kurihara H, Kimura S, et al. A novel potent vasoconstrictor peptide produced by vascular endothelial cells. Nature 1988;332:411-5. [PubMed: 2451132]

23. Fagan KA, McMurtry IF, Rodman DM. Role of endothelin-1 in lung disease. Respir Res 2001;2:90-101. [PubMed: 11686871]

24. Haynes WG, Webb DJ. Contribution of endogenous generation of endothelin-1 to basal vascular tone. Lancet 1994;344:852-4. [PubMed: 7916401]

25. Hahn AW, Resink TJ, Scott-Burden T, et al. Stimulation of endothelin mRNA and secretion in rat vascular smooth muscle cells: a novel autocrine function. Cell Regul 1990;1:649-59. [PubMed: 2078571]

26. Ito H, Hirata Y, Adachi S, et al. Endothelin-1 is an autocrine/para-crine factor in the mechanism of angiotensin II-induced hypertrophy in cultured rat cardiomyocytes. J Clin Invest 1993;92:398403. [PubMed: 8326007]

27. Ehrenreich H, Anderson RW, Fox CH, et al. Endothelins, peptides with potent vasoactive properties, are produced by human macrophages. J Exp Med 1990;172:1741-8. [PubMed: 1701822]

28. Fukunaga M, Fujiwara Y, Ochi S, et al. Stimulatory effect of thrombin on endothelin-1 production in isolated glomeruli and cultured mesangial cells of rats. J Cardiovasc Pharmacol 1991;17:S4113. [PubMed: 1725395]

29. Nakamura T, Ebihara I, Fukui M, et al. Renal expression of mRNAs for endothelin-1, endothelin-3 and endothelin receptors in NZB/W F1 mice. Ren Physiol Biochem 1993;16:233-43. [PubMed: 7694336]

30. Blouquit S, Sari A, Lombet A, et al. Effects of endothelin-1 on epithelial ion transport in human airways. Am J Respir Cell Mol Biol 2003;29:245-51. [PubMed: 12626340]

31. Henry PJ. Endothelin receptor distribution and function in the airways. Clin Exp Pharmacol Physiol 1999;26:162-7. [PubMed: 10065340]

32. Marciniak SJ, Plumpton C, Barker PJ, Huskisson NS, Davenport AP. Localization of immunoreactive endothelin and proendothelin in the human lung. Pulm Pharmacol 1992;5:175-82. [PubMed: 1446139]

33. Jain R, Shaul PW, Borok Z, Willis BC. Endothelin-1 induces alveolar epithelial-mesenchymal transition through endothelin type A receptor-mediated production of TGF-beta1. Am J Respir Cell Mol Biol 2007;37:38-47. [PubMed: 17379848]

34. Comellas AP, Briva A, Dada LA, et al. Endothelin-1 impairs alveolar epithelial function via endothelial ETB receptor. Am J Respir Crit Care Med 2009;179:113-22. [PubMed: 18948426] 
35. Frank JA, Briot R, Lee JW, et al. Physiological and biochemical markers of alveolar epithelial barrier dysfunction in perfused human lungs. Am J Physiol Lung Cell Mol Physiol 2007;293:L529. [PubMed: 17351061]

36. Marasciulo FL, Montagnani M, Potenza MA. Endothelin-1: the yin and yang on vascular function. Curr Med Chem 2006;13:1655-65. [PubMed: 16787211]

37. Luscher TF, Barton M. Endothelins and endothelin receptor antagonists: therapeutic considerations for a novel class of cardiovascular drugs. Circulation 2000;102:2434-40. [PubMed: 11067800]

38. Muldoon LL, Rodland KD, Forsythe ML, Magun BE. Stimulation of phosphatidylinositol hydrolysis, diacylglycerol release, and gene expression in response to endothelin, a potent new agonist for fibroblasts and smooth muscle cells. J Biol Chem 1989;264:8529-36. [PubMed: 2656683]

39. Schiffrin EL, Touyz RM. Vascular biology of endothelin. J Cardiovasc Pharmacol 1998;32:S2-13. [PubMed: 9883741]

40. Clavell AL, Stingo AJ, Margulies KB, Brandt RR, Burnett JC Jr. Role of endothelin receptor subtypes in the in vivo regulation of renal function. Am J Physiol 1995;268:F455-60. [PubMed: 7900845]

41. Lysko PG, Elshourbagy NA, Pullen M, Nambi P. Developmental expression of endothelin receptors in cerebellar neurons differentiating in culture. Brain Res Dev Brain Res 1995;88:96101.

42. Rockey DC, Chung JJ. Regulation of inducible nitric oxide synthase in hepatic sinusoidal endothelial cells. Am J Physiol 1996;271:G260-7. [PubMed: 8770041]

43. Rockey DC, Chung JJ. Endothelin antagonism in experimental hepatic fibrosis. Implications for endothelin in the pathogenesis of wound healing. J Clin Invest 1996;98:1381-8. [PubMed: 8823303]

44. Strachan FE, Spratt JC, Wilkinson IB, et al. Systemic blockade of the endothelin-B receptor increases peripheral vascular resistance in healthy men. Hypertension 1999;33:581-5. [PubMed: 9931169]

45. de Nucci G, Thomas R, D'Orleans-Juste P, et al. Pressor effects of circulating endothelin are limited by its removal in the pulmonary circulation and by the release of prostacyclin and endothelium-derived relaxing factor. Proc Natl Acad Sci U S A 1988;85:9797-800. [PubMed: 3059352]

46. Hirata Y, Emori T, Eguchi S, et al. Endothelin receptor subtype B mediates synthesis of nitric oxide by cultured bovine endothelial cells. J Clin Invest 1993;91:1367-73. [PubMed: 7682570]

47. D'Orleans-Juste P, Labonte J, Bkaily G, et al. Function of the endothelin(B) receptor in cardiovascular physiology and pathophysiology. Pharmacol Ther 2002;95:221-38. [PubMed: 12243796]

48. Liu S, Premont RT, Kontos CD, Huang J, Rockey DC. Endothelin-1 activates endothelial cell nitric-oxide synthase via heterotrimeric G-protein betagamma subunit signaling to protein jinase B/Akt. J Biol Chem 2003;278:49929-35. [PubMed: 14523027]

49. Scotland R, Vallance P, Ahluwalia A. Endothelin alters the reactivity of vasa vasorum: mechanisms and implications for conduit vessel physiology and pathophysiology. Br J Pharmacol 1999;128:1229-34. [PubMed: 10578136]

50. Dupuis J, Stewart DJ, Cernacek P, Gosselin G. Human pulmonary circulation is an important site for both clearance and production of endothelin-1. Circulation 1996;94:1578-84. [PubMed: 8840847]

51. Nakano Y, Tasaka S, Saito F, et al. Endothelin-1 level in epithelial lining fluid of patients with acute respiratory distress syndrome. Respirology 2007;12:740-3. [PubMed: 17875064]

52. Helset E, Kjaeve J, Hauge A. Endothelin-1-induced increases in microvascular permeability in isolated, perfused rat lungs requires leukocytes and plasma. Circ Shock 1993;39:15-20. [PubMed: 8481973]

53. Lehoux S, Plante GE, Sirois MG, Sirois P, D’Orleans-Juste P. Phosphoramidon blocks bigendothelin-1 but not endothelin-1 enhancement of vascular permeability in the rat. Br J Pharmacol 1992;107:996-1000. [PubMed: 1467845] 
54. Rodman DM, Stelzner TJ, Zamora MR, et al. Endothelin-1 increases the pulmonary microvascular pressure and causes pulmonary edema in salt solution but not blood-perfused rat lungs. J Cardiovasc Pharmacol 1992;20:658-63. [PubMed: 1280724]

55. Kuzkov VV, Kirov MY, Sovershaev MA, et al. Extravascular lung water determined with single transpulmonary thermodilution correlates with the severity of sepsis-induced acute lung injury. Crit Care Med 2006;34:1647-53. [PubMed: 16625129]

56. Kosmidou I, Karmpaliotis D, Kirtane AJ, Barron HV, Gibson CM. Vascular endothelial growth factors in pulmonary edema: an update. J Thromb Thrombolysis 2008;25:259-64. [PubMed: 17554593]

57. Horgan MJ, Pinheiro JM, Malik AB. Mechanism of endothelin-1-induced pulmonary vasoconstriction. Circ Res 1991;69:157-64. [PubMed: 2054931]

58. Kuklin V, Kirov M, Sovershaev M, et al. Tezosentan-induced attenuation of lung injury in endotoxemic sheep is associated with reduced activation of protein kinase C. Crit Care 2005;9:R211-7. [PubMed: 15987392]

59. Matsuura A, Yamochi W, Hirata K, Kawashima S, Yokoyama M. Stimulatory interaction between vascular endothelial growth factor and endothelin-1 on each gene expression. Hypertension 1998;32:89-95. [PubMed: 9674643]

60. Carpenter TC, Schomberg S, Stenmark KR. Endothelin-mediated increases in lung VEGF content promote vascular leak in young rats exposed to viral infection and hypoxia. Am J Physiol Lung Cell Mol Physiol 2005;289:L1075-82. [PubMed: 16040626]

61. Spinella F, Rosano L, Di Castro V, Natali PG, Bagnato A. Endothelin-1 induces vascular endothelial growth factor by increasing hypoxia-inducible factor-1alpha in ovarian carcinoma cells. J Biol Chem 2002;277:27850-5. [PubMed: 12023962]

62. Kaner RJ, Ladetto JV, Singh R, et al. Lung overexpression of the vascular endothelial growth factor gene induces pulmonary edema. Am J Respir Cell Mol Biol 2000;22:657-64. [PubMed: 10837361]

63. Fujii Y, Magder S, Cernacek P, et al. Endothelin receptor blockade attenuates lipopolysaccharideinduced pulmonary nitric oxide production. Am J Respir Crit Care Med 2000;161:982-9. [PubMed: 10712352]

64. Michael JR, Markewitz BA. Endothelins and the lung. Am J Respir Crit Care Med 1996;154:55581. [PubMed: 8810589]

65. Wang J, Oldner A, Winskog C, Edston E, Walther SM. Effects of endothelin receptor antagonism on acute lung injury induced by chlorine gas. Crit Care Med 2006;34:1731-7. [PubMed: 16625121]

66. Carpenter TC, Stenmark KR. Endothelin receptor blockade decreases lung water in young rats exposed to viral infection and hypoxia. Am J Physiol Lung Cell Mol Physiol 2000;279:L547-54. [PubMed: 10956630]

67. Ishizaki T, Shigemori K, Nakai T, et al. Endothelin-1 potentiates leukotoxin-induced edematous lung injury. J Appl Physiol 1995;79:1106-11. [PubMed: 8567550]

68. Albertini M, Clement MG, Hussain SN. Role of endothelin ETA receptors in sepsis-induced mortality, vascular leakage, and tissue injury in rats. Eur J Pharmacol 2003;474:129-35. [PubMed: 12909204]

69. Guimaraes CL, Trentin PG, Rae GA. Endothelin ET(B) receptor-mediated mechanisms involved in oleic acid-induced acute lung injury in mice. Clin Sci 2002;103:340S-4S. [PubMed: 12193118]

70. Carpenter T, Schomberg S, Steudel W, et al. Endothelin B receptor deficiency predisposes to pulmonary edema formation via increased lung vascular endothelial cell growth factor expression. Circ Res 2003;93:456-63. [PubMed: 12919946]

71. Gariepy CE, Cass DT, Yanagisawa M. Null mutation of endothelin receptor type B gene in spotting lethal rats causes aganglionic megacolon and white coat color. Proc Natl Acad Sci U S A 1996;93:867-72. [PubMed: 8570650]

72. Ivy D, McMurtry IF, Yanagisawa M, et al. Endothelin B receptor deficiency potentiates ET-1 and hypoxic pulmonary vasoconstriction. Am J Physiol Lung Cell Mol Physiol 2001;280:L1040-8. [PubMed: 11290529]

73. Staub NC. Pulmonary edema. Physiol Rev 1974;54:678-811. [PubMed: 4601625] 
74. Dada LA, Sznajder JI. Mechanisms of pulmonary edema clearance during acute hypoxemic respiratory failure: role of the Na, K-ATPase. Crit Care Med 2003;31:S248-52. [PubMed: 12682448]

75. Matthay MA, Landolt CC, Staub NC. Differential liquid and protein clearance from the alveoli of anesthetized sheep. J Appl Physiol 1982;53:96-104. [PubMed: 7118651]

76. Goodman BE, Brown SE, Crandall ED. Regulation of transport across pulmonary alveolar epithelial cell monolayers. J Appl Physiol 1984;57:703-10. [PubMed: 6149212]

77. Matthay MA, Folkesson HG, Verkman AS. Salt and water transport across alveolar and distal airway epithelia in the adult lung. Am J Physiol 1996;270:L487-503. [PubMed: 8928808]

78. Effros RM, Mason GR, Sietsema K, Silverman P, Hukkanen J. Fluid reabsorption and glucose consumption in edematous rat lungs. Circ Res 1987;60:708-19. [PubMed: 3109762]

79. Effros RM, Mason GR, Hukkanen J, Silverman P. New evidence for active sodium transport from fluid-filled rat lungs. J Appl Physiol 1989;66:906-19. [PubMed: 2708220]

80. Ware LB, Matthay MA. Alveolar fluid clearance is impaired in the majority of patients with acute lung injury and the acute respiratory distress syndrome. Am J Respir Crit Care Med 2001;163:1376-83. [PubMed: 11371404]

81. Sznajder JI. Alveolar edema must be cleared for the acute respiratory distress syndrome patient to survive. Am J Respir Crit Care Med 2001;163:1293-4. [PubMed: 11371384]

82. Matthay MA, Robriquet L, Fang X. Alveolar epithelium: role in lung fluid balance and acute lung injury. Proc Am Thorac Soc 2005;2:206-13. [PubMed: 16222039]

83. Kaplan JH. Biochemistry of Na, K-ATPase. Annu Rev Biochem 2002;71:511-35. [PubMed: 12045105]

84. Skou JC. Nobel Lecture. The identification of the sodium pump. Biosci Rep 1998;18:155-69. [PubMed: 9877230]

85. Briva A, Vadasz I, Lecuona E, et al. High CO(2) levels impair alveolar epithelial function independently of pH. PLoS ONE 2007;2:e1238. [PubMed: 18043745]

86. Comellas AP, Dada LA, Lecuona E, et al. Hypoxia-mediated degradation of Na, K-ATPase via mitochondrial reactive oxygen species and the ubiquitin-conjugating system. Circ Res 2006;98:1314-22. [PubMed: 16614303]

87. Dada LA, Chandel NS, Ridge KM, et al. Hypoxia-induced endocytosis of Na, K-ATPase in alveolar epithelial cells is mediated by mitochondrial reactive oxygen species and PKC-zeta. J Clin Invest 2003;111:1057-64. [PubMed: 12671055]

88. Vadasz I, Morty RE, Olschewski A, et al. Thrombin impairs alveolar fluid clearance by promoting endocytosis of Na+, K+-ATPase. Am J Respir Cell Mol Biol 2005;33:343-54. [PubMed: 16014898]

89. Factor P, Dumasius V, Saldias F, Brown LA, Sznajder JI. Adeno-virus-mediated transfer of an Na +/K+-ATPase beta1 subunit gene improves alveolar fluid clearance and survival in hyperoxic rats. Hum Gene Ther 2000;11:2231-42. [PubMed: 11084680]

90. Factor P, Dumasius V, Saldias F, Sznajder JI. Adenoviral-mediated overexpression of the NA, KATPase beta1 subunit gene increases lung edema clearance and improves survival during acute hyperoxic lung injury in rats. Chest 1999;116:24S-5S. [PubMed: 10424567]

91. Myrianthefs PM, Briva A, Lecuona E, et al. Hypocapnic but not metabolic alkalosis impairs alveolar fluid reabsorption. Am J Respir Crit Care Med 2005;171:1267-71. [PubMed: 15764729]

92. Sugita M, Ferraro P, Dagenais A, et al. Alveolar liquid clearance and sodium channel expression are decreased in transplanted canine lungs. Am J Respir Crit Care Med 2003;167:1440-50. [PubMed: 12738601]

93. Cher CD, Armugam A, Lachumanan R, Coghlan MW, Jeyaseelan K. Pulmonary inflammation and edema induced by phospholipase A2: global gene analysis and effects on aquaporins and $\mathrm{Na}+\mathrm{K}+-$ ATPase. J Biol Chem 2003;278:31352-60. [PubMed: 12746451]

94. Litvan J, Briva A, Wilson MS, et al. Beta-adrenergic receptor stimulation and adenoviral overexpression of superoxide dismutase prevent the hypoxia-mediated decrease in Na, K-ATPase and alveolar fluid reabsorption. J Biol Chem 2006;281:19892-8. [PubMed: 16636055]

95. Dempsey EC, Cool CD, Littler CM. Lung disease and PKCs. Pharmacol Res 2007;55:545-59. [PubMed: 17582782] 
96. Fink MP. Role of reactive oxygen and nitrogen species in acute respiratory distress syndrome. Curr Opin Crit Care 2002;8:6-11. [PubMed: 12205400]

97. Modesti PA, Vanni S, Morabito M, et al. Role of endothelin-1 in exposure to high altitude: Acute mountain sickness and endothelin-1 (ACME-1) study. Circulation 2006;114:1410-6. [PubMed: 16982943]

98. Kourembanas S, Marsden PA, McQuillan LP, Faller DV. Hypoxia induces endothelin gene expression and secretion in cultured human endothelium. J Clin Invest 1991;88:1054-7. [PubMed: 1885767]

99. Clerici C, Matthay MA. Hypoxia regulates gene expression of alveolar epithelial transport proteins. J Appl Physiol 2000;88:1890-6. [PubMed: 10797154]

100. Mairbaurl H, Wodopia R, Eckes S, Schulz S, Bartsch P. Impairment of cation transport in A549 cells and rat alveolar epithelial cells by hypoxia. Am J Physiol 1997;273:L797-806. [PubMed: 9357855]

101. Vivona ML, Matthay M, Chabaud MB, Friedlander G, Clerici C. Hypoxia reduces alveolar epithelial sodium and fluid transport in rats: reversal by beta-adrenergic agonist treatment. Am J Respir Cell Mol Biol 2001;25:554-61. [PubMed: 11713096]

102. Knowles MR, Carson JL, Collier AM, Gatzy JT, Boucher RC. Measurements of nasal transepithelial electric potential differences in normal human subjects in vivo. Am Rev Respir Dis 1981;124:484-90. [PubMed: 7294508]

103. Mairbaurl H, Weymann J, Mohrlein A, et al. Nasal epithelium potential difference at high altitude (4,559 m): evidence for secretion. Am J Respir Crit Care Med 2003;167:862-7. [PubMed: 12522027]

104. Sartori C, Duplain H, Lepori M, et al. High altitude impairs nasal transepithelial sodium transport in HAPE-prone subjects. Eur Respir J 2004;23:916-20. [PubMed: 15219007]

105. Scherrer U, Vollenweider L, Delabays A, et al. Inhaled nitric oxide for high-altitude pulmonary edema. N Engl J Med 1996;334:624-9. [PubMed: 8592525]

106. Ghofrani HA, Reichenberger F, Kohstall MG, et al. Sildenafil increased exercise capacity during hypoxia at low altitudes and at Mount Everest base camp: a randomized, double-blind, placebocontrolled crossover trial. Ann Intern Med 2004;141:169-77. [PubMed: 15289213]

107. Berger MM, Rozendal CS, Schieber C, et al. The effect of endothelin-1 on alveolar fluid clearance and pulmonary edema formation in the rat. Anesth Analg 2009;108:225-31. [PubMed: 19095854]

108. Guo Y, DuVall MD, Crow JP, Matalon S. Nitric oxide inhibits Na+ absorption across cultured alveolar type II monolayers. Am J Physiol 1998;274:L369-77. [PubMed: 9530172]

109. Hardiman KM, McNicholas-Bevensee CM, Fortenberry J, et al. Regulation of amiloride-sensitive $\mathrm{Na}(+)$ transport by basal nitric oxide. Am J Respir Cell Mol Biol 2004;30:720-8. [PubMed: 14607816]

110. Hickman-Davis JM, McNicholas-Bevensee C, Davis IC, et al. Reactive species mediate inhibition of alveolar type II sodium transport during mycoplasma infection. Am J Respir Crit Care Med 2006;173:334-44. [PubMed: 16254273]

111. Jain L, Chen XJ, Brown LA, Eaton DC. Nitric oxide inhibits lung sodium transport through a cGMP-mediated inhibition of epithelial cation channels. Am J Physiol 1998;274:L475-84. [PubMed: 9575865]

112. Kaestle SM, Reich CA, Yin N, et al. Nitric oxide-dependent inhibition of alveolar fluid clearance in hydrostatic lung edema. Am J Physiol Lung Cell Mol Physiol 2007;293:L859-69. [PubMed: 17616651]

113. Nielsen VG, Baird MS, Chen L, Matalon S. DETANONOate, a nitric oxide donor, decreases amiloride-sensitive alveolar fluid clearance in rabbits. Am J Respir Crit Care Med 2000;161:1154-60. [PubMed: 10764305]

114. Berthiaume Y, Staub NC, Matthay MA. Beta-adrenergic agonists increase lung liquid clearance in anesthetized sheep. J Clin Invest 1987;79:335-43. [PubMed: 2879851]

115. Ewart HS, Klip A. Hormonal regulation of the $\mathrm{Na}(+)-\mathrm{K}(+)-A T P a s e:$ mechanisms underlying rapid and sustained changes in pump activity. Am J Physiol 1995;269:C295-311. [PubMed: $7653511]$ 
116. Ghofrani HA, Kohstall MG, Weissmann N, et al. Alveolar epithelial barrier functions in ventilated perfused rabbit lungs. Am J Physiol Lung Cell Mol Physiol 2001;280:L896-904. [PubMed: 11290513]

117. Pittet JF, Wiener-Kronish JP, McElroy MC, Folkesson HG, Matthay MA. Stimulation of lung epithelial liquid clearance by endogenous release of catecholamines in septic shock in anesthetized rats. J Clin Invest 1994;94:663-71. [PubMed: 8040320]

118. Saldias FJ, Lecuona E, Comellas AP, et al. beta-adrenergic stimulation restores rat lung ability to clear edema in ventilator-associated lung injury [In Process Citation]. Am J Respir Crit Care Med 2000;162:282-7. [PubMed: 10903255]

119. Bertorello AM, Ridge KM, Chibalin AV, Katz AI, Sznajder JI. Isoproterenol increases Na+-K+ATPase activity by membrane insertion of alpha-subunits in lung alveolar cells. Am J Physiol 1999;276:L20-7. [PubMed: 9887051]

120. Chibalin AV, Katz AI, Berggren PO, Bertorello AM. Receptor-mediated inhibition of renal $\mathrm{Na}(+)-\mathrm{K}(+)$-ATPase is associated with endocytosis of its alpha- and beta-subunits. Am J Physiol 1997;273:C1458-65. [PubMed: 9374629]

121. Lecuona E, Dada LA, Sun H, et al. Na, K-ATPase alpha1-subunit dephosphorylation by protein phosphatase $2 \mathrm{~A}$ is necessary for its recruitment to the plasma membrane. FASEB J 2006;20:2618-20. [PubMed: 17065225]

122. Lecuona E, Ridge K, Pesce L, Batlle D, Sznajder JI. The GTP-binding protein RhoA mediates Na, K-ATPase exocytosis in alveolar epithelial cells. Mol Biol Cell 2003;14:3888-97. [PubMed: 12972572]

123. Perkins GD, McAuley DF, Thickett DR, Gao F. The beta-agonist lung injury trial (BALTI): a randomized placebo-controlled clinical trial. Am J Respir Crit Care Med 2006;173:281-7. [PubMed: 16254268]

124. Sartori C, Allemann Y, Duplain H, et al. Salmeterol for the prevention of high-altitude pulmonary edema. N Engl J Med 2002;346:1631-6. [PubMed: 12023995]

125. Matthay MA, Calfee CS. Aerosolized beta-adrenergic agonist therapy reduces pulmonary edema following lung surgery. Chest 2008;133:833-5. [PubMed: 18398109]

126. Rutschman DH, Olivera W, Sznajder JI. Active transport and passive liquid movement in isolated perfused rat lungs. J Appl Physiol 1993;75:1574-80. [PubMed: 8282606]

\section{Biography}

Alejandro Comellas, MD, is Assistant Professor in the Department of Internal Medicine in the Division of Pulmonary, Critical Care and Occupational Medicine at the University of Iowa. His article is based on a presentation given at the Combined Annual Meeting of the Central Society for Clinical Research and Midwestern Section American Federation for Medical Research held in Chicago, Ill, April 2008. 


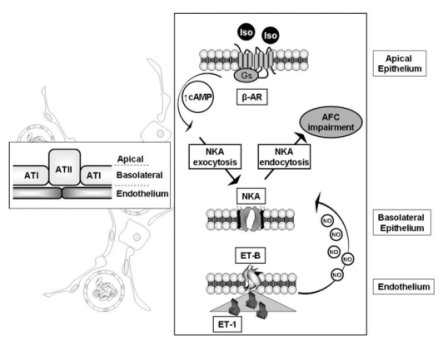

Fig 1.

Schematic representation of the effect of both ET- 1 and $\beta$-adrenergic agonist on the $\mathrm{Na}, \mathrm{K}$ ATPase abundance at the basolateral membrane in alveolar epithelial cells. ET-1 activates endothelial ET-B receptors that lead to NO generation, which in turn causes endocytosis of the $\mathrm{Na}, \mathrm{K}$-ATPase in alveolar epithelial cells. Conversely, activation of $\beta$-adrenergic receptors by isoproterenol leads to the translocation of the $\mathrm{Na}, \mathrm{K}$-ATPase to the basolateral membrane in alveolar epithelial cells. $\beta$ - $A R$, beta-adrenergic receptor. 


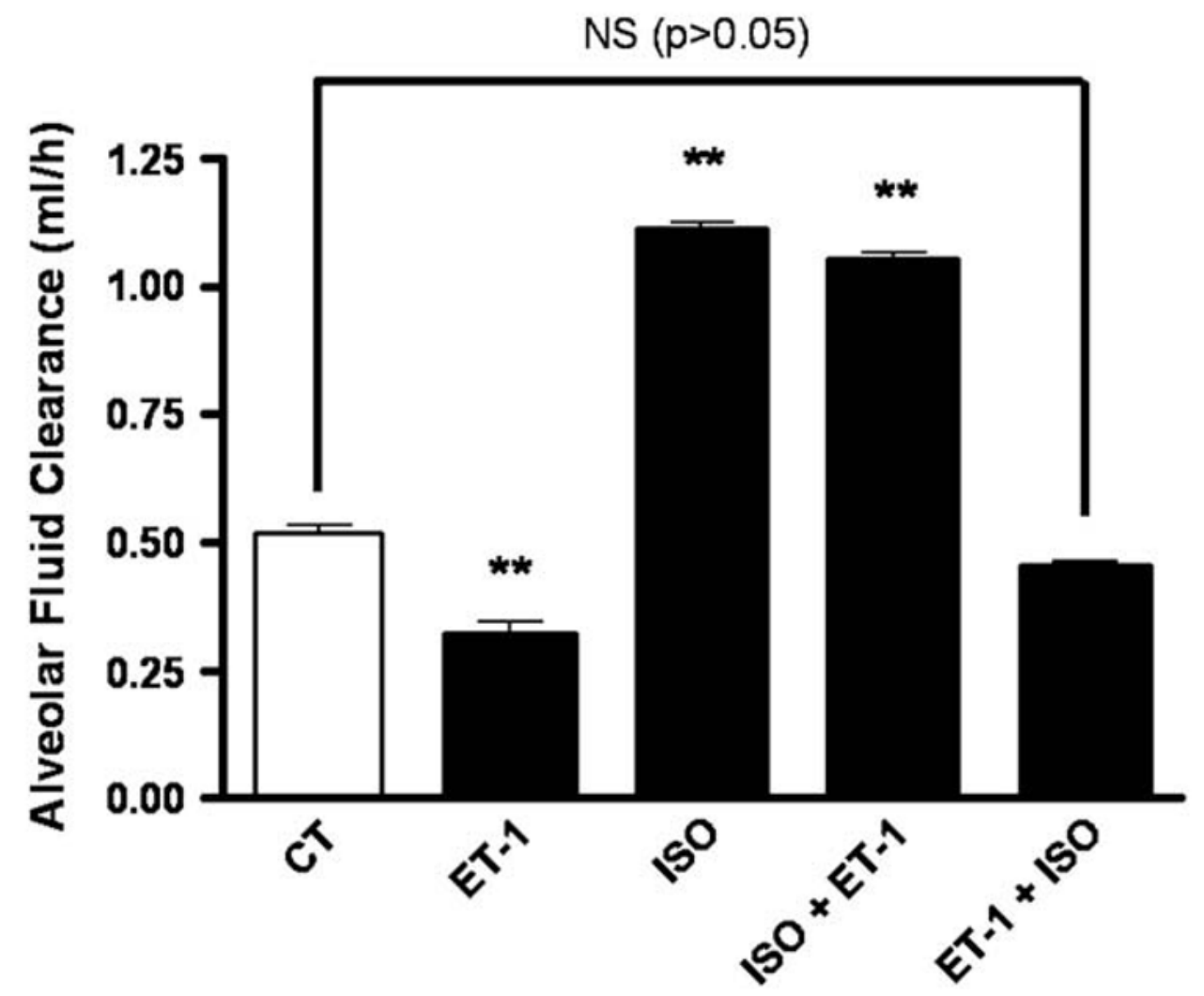

Fig 2.

Iso prevents ET-1 decrease in alveolar fluid clearance in isolated perfused rat lungs. Isolated rat lungs were treated for $1 \mathrm{~h}$ with vehicle (CT), ET- $1\left(10^{-7} \mathrm{~mol} / \mathrm{L}\right.$ in perfusate), Iso $\left(10^{-6}\right.$ $\mathrm{mol} / \mathrm{L}$ in the instillate); Iso in the instillate $\left(10^{-6}\right)$ for $30 \mathrm{~min}$, followed by ET-1 in the perfusate $\left(10^{-7}\right)$ for $30 \mathrm{~min}$ (Iso + ET-1); and ET-1 in the perfusate $\left(10^{-7}\right)$ for $30 \mathrm{~min}$, followed by Iso in the instillate $\left(10^{-6}\right)$ for $30 \mathrm{~min}$. AFC was measured as described previously $34,126(\mathrm{n}=6)$. Graph represents mean \pm standard error of the mean. $* * P<0.01$. NS $=$ nonstatistically significant. 